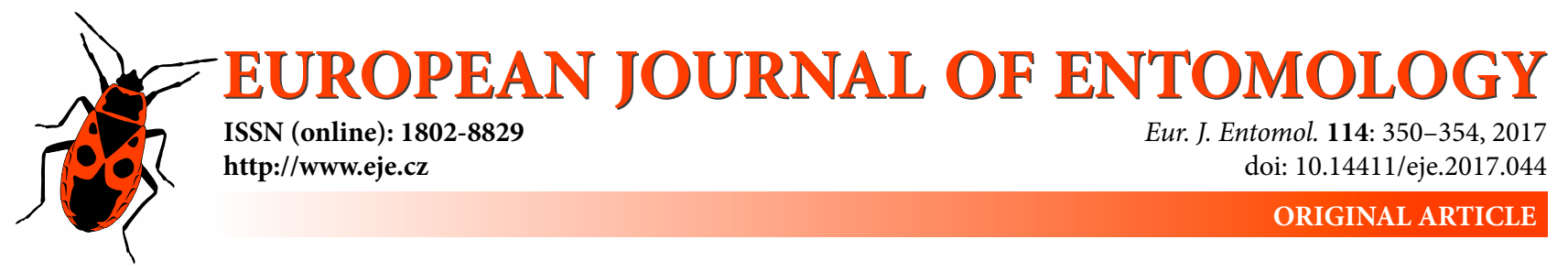

\title{
A "clean" alien species? Parasites of the invasive ladybird Harmonia axyridis (Coleoptera: Coccinellidae)
}

\author{
KRzYsztof DUdeK ${ }^{1}$, Pawer SIENKIEWICZ ${ }^{2}$, Dariusz J. GWIAZDOWICZ ${ }^{3}$ and PIotr TRYJANOWSKI ${ }^{1}$ \\ ${ }^{1}$ Department of Zoology, Institute of Zoology, Poznań University of Life Sciences, Wojska Polskiego 71C, 60-625 Poznań, \\ Poland; e-mails: dudeekk@gmail.com, piotr.tryjanowski@gmail.com \\ ${ }^{2}$ Department of Entomology and Environmental Protection, Poznań University of Life Sciences, Dąbrowskiego 159, \\ 60-594 Poznań, Poland; e-mail: ophonus@gmail.com \\ ${ }^{3}$ Department of Forest Pathology, Poznań University of Life Sciences, Wojska Polskiego 71C, 60-625 Poznań, Poland; \\ e-mail: dagwiazd@up.poznan.pl
}

Key words. Coleoptera, Coccinellidae, Harmonia axyridis, eugregarines, fungi, nematodes, phoretic mites, insect ecology

\begin{abstract}
The multicoloured Asian ladybird Harmonia axyridis is an invasive insect that can negatively influence biodiversity and human economy in invaded areas. According to the enemy release hypothesis, invasive alien species are often little affected by parasites and other enemies. We studied the prevalence of common parasites of insects infesting and infecting $H$. axyridis in NW Poland. A large sample of 2351 individuals was collected and divided into two groups: 1180 beetles were dissected and examined for the presence of eugregarines, nematodes and Laboulbeniales fungi, and 751 were checked for phoretic mites. Our results show that $H$. axyridis is indeed parasitized infrequently. The prevalence of eugregarines and nematodes was very low $(1.5 \%$ and $0.4 \%$, respectively). No specimens of Laboulbeniales or phoretic mites were found. Our study indicates that in NW Poland $H$. axyridis is rarely infested or infected by parasites. This paper reports for the first time the infection of $H$. axyridis by the eugregarine Gregarina barbarara.
\end{abstract}

\section{INTRODUCTION}

One of the reasons for rapid and successful invasions by non native species might be their escape from natural enemies - "enemy release hypothesis" (Torchin et al., 2003; Colautti et al., 2004; Heger \& Jeschke, 2014). Many studies have shown that invaders are less parasitized and less prone to attack from predators in invaded areas than native species, and this is recorded for many species of plants (Keane \& Crawley, 2002; Mitchell \& Power, 2003) and animals (Torchin et al., 2002; Carroll et al., 2005). Apart from the studies supporting the enemy release hypothesis, there are also many studies questioning it (Heger \& Jeschke, 2014). There is some evidence, however, that the enemy release hypothesis might partly explain one of the most rapid and widespread insect invasions of recent years, namely that of the multicoloured Asian ladybird Harmonia axyridis (Roy et al., 2011; Haelewaters et al., 2017).

The main goal of this study was to search for common parasites of ladybirds infesting $H$. axyridis in an invaded area (NW Poland): eugregarines, fungi and mites. These organisms are often found to infect/infest insects, so they may decrease insect survival and play an important role in the worldwide spread of $H$. axyridis. However, in this study we did not investigate parasitoids, such as Dinocam- pus coccinellae and Phalacrotophora spp., which may also contribute to the suppression of the invader (Ware et al., 2010).

\section{Eugregarines}

Eugregarines are protozoans that commonly parasitize insects (Clopton et al., 2002). Gregarine infections may decrease insect fitness and percentage survival (Logan et al., 2012; Bollatti \& Ceballos, 2014), and massive infestation of the gut may be even lethal for hosts (Lipa, 1967). A laboratory study of the Blattodea has shown that infestation by gregarines predisposes the hosts to parasitism by other, more dangerous microorganisms (Lopes \& Alves, 2005). Gregarines vary in specificity, some infest hosts from closely related taxonomic groups but most have a broad range of hosts (Geus, 1969). In the guts of Coccinellidae, 12 species of gregarines, with host spectra ranging between 1 and 9 coccinellid species, are recorded (Ceryngier et al., 2012). Species with a broad spectrum of hosts include Gregarina barbarara (7 hosts) and G. katherina (9 hosts). Both of these species of gregarine occur in the USA and the central part of Europe (Ceryngier et al., 2012). However, there is a lack of published data on gregarines infecting H. axyridis (Roy et al., 2011). 


\section{Nematodes}

The Coccinellidae are mostly infested by nematodes of the families Allantonematidae and Mermithidae (Ceryngier et al., 2012). Nematodes penetrate into the body cavity of coccinellids through tracheae and soft parts of the cuticle. Transmission may be facilitated when coccinellids aggregate during winter (Ceryngier \& Hodek, 1996). Consequences of infestation vary from general weakness to death. Parasitylenchus coccinellinae retards maturation of the ovaries and decreases fat supplies (Ceryngier \& Hodek, 1996). Howardula sp. causes a reduction in the body size of its hosts, larvae of Adalia bipunctata (El-Hariri, 1966). Infestation by mermithid nematodes is fatal for ladybirds, as the nematodes destroy organs of the insects, resulting in death 17 days after infestation (Rhamhalinghan, 1987b, a). Laboratory studies have shown lethal effects of Steinernema carpocapsae on H. axyridis (Lemire et al., 1996), but there are no reports of infections by this nematode in the field. European populations of $H$. axyridis are infected by Parasitylenchus bifurcatus (Poinar \& Steenberg, 2012; Haelewaters et al., 2017).

\section{Fungi}

The importance of fungi that could keep the population of insects at a low level is well known and described in many papers (Nikiforov, 1970; Vorontsov, 1995; Tarasco et al., 1997). Many fungi are considered to be biological control agents of insects damaging agricultural, horticultural and forest crops (Inglis et al., 2001; Pell et al., 2001). Coccinellids in their natural environment are infested by many species of fungi e.g. endoparasitic Hesperomyces virescens (Haelewaters et al., 2014), and entomopathogenic Beauveria bassiana (Cottrell \& Shapiro-Ilan, 2003), Metarhizium anisopliae (Ginsberg et al., 2002), Isaria farinosa, I. fumosorosea, and Lecanicillium lecanii (Ceryngier \& Hodek, 1996).

Majority of the knowledge about fungi in ladybirds is from studies on fungi as biopesticides in which coccinellids are non-target insects (Pingel \& Lewis, 1996; Todorova et al., 1996; Roy \& Pell, 2000; Pell \& Vandenberg, 2002). $H$. axyridis is known as a host of Hesperomyces virescens in invaded areas in the Americas, Europe and South Africa (Haelewaters et al., 2017). Studies on B. bassiana have shown that $H$. axyridis is rather resistant to this pathogen (Cottrell \& Shapiro-Ilan, 2003; Roy et al., 2008). Vilcinskas et al. (2013) suggest that this resistance may be related to a variety of antimicrobial peptides synthesized by $H$. axyridis.

\section{Mites}

Mites associated with ladybirds may be either parasitic or phoretic (Ceryngier et al., 2012). Phoresy is a specific nonparasitic relationship, wherein the mites (Acarina) use different taxonomic groups of animals only for transport (Gwiazdowicz, 2000). Nonetheless, phoresy is a strong stressor for the host insect (Gudowska et al., 2015). Moreover, mites could be vectors of a wide range of bacterial, fungal and protozoan pathogens or viruses (Poinar \& Poinar, 1998). Thus determining the presence of these organ- isms complements the search for parasites and pathogens of $H$. axyridis. In the context of phoretic relationships, $H$. axyridis has never been investigated. Other coccinellids carry some phoretic species of mites (Hurst et al., 1997).

\section{MATERIAL AND METHODS}

\section{Collection of material}

The beetles used in this study were collected on a wind farm located west of Gołańcz in the Wielkopolska region in NW Poland $\left(52^{\circ} 57^{\prime} \mathrm{N}, 17^{\circ} 14^{\prime} \mathrm{E}\right)$. The wind farm is in an intensive agricultural landscape dominated by oilseed rape and corn fields. Insects were collected in October and November 2015 on 16 wind turbines (for details of habitat see Dudek et al., 2015). The total of 2351 individuals of $H$. axyridis was divided randomly into 2 groups. The largest group of 1180 individuals was used for searching for eugregarines, nematodes and Laboulbeniales fungi, and the remaining 751 beetles were checked for mites.

\section{Laboulbeniales, eugregarines and nematodes}

The group of 1180 individuals of $H$. axyridis were sexed, checked under a stereomicroscope for the presence of Laboulbeniales, and then their guts were dissected and searched for parasites and pathogens. The digestive tract was dissected in a saline solution and checked under a microscope for the presence of gregarines and nematodes. The total number of gregarines and nematodes in the gut contents was recorded. Gregarines were identified to species on the basis of microscopic measurements, according to Geus (1969) and Lipa (1967). The nematodes were determined using the online key by Nguyen (2010). It is important to know whether the nematodes infecting coccinellids live inside their body cavities, thus searching the digestive tract may detect only individuals penetrating through the gut wall.

\section{Mites}

Sample of ladybirds was stored in $75 \%$ ethanol before checking for the presence of mites. Both the body surface and the spaces under the elytra were examined under a stereomicroscope.

\section{Statistical analyses}

Statistical analyses of the prevalence of gregarines and nematodes, confidence limits, and infestation levels were determined using Quantitative Parasitology 3.0 software (Rózsa et al., 2000), and chi-square tests using SPSS ver. 21 software.

\section{RESULTS}

The large sample of overwintering $H$. axyridis ladybirds collected from the wind farm was strongly female-biased: 778 females and only 402 males (chi-square with Yates correction $\chi^{2}=60.81, p<0.0001$ ). Only gregarines and nematodes (and no Laboulbeniales and mites) were recorded.

Gregarines were found in 18 specimens (11 males and 7 females). Total prevalence was $1.5 \%$, with a median number of 49 (90\% confidence interval: 5-110) individuals per host, and dispersion index (variance/mean ratio) of 249.84 . Infestation with gregarines was sex-biased, with a higher prevalence in males $(2.7 \%$ with a median number of 60 individuals per host $v$ s. $0.9 \%$ with a median number of 21 , respectively; chi-square with Yates correction $\chi^{2}=4.605, p$ $=0.031)$. All the gregarines were identified as Gregarina barbarara Watson, 1915 (Fig. 1). 


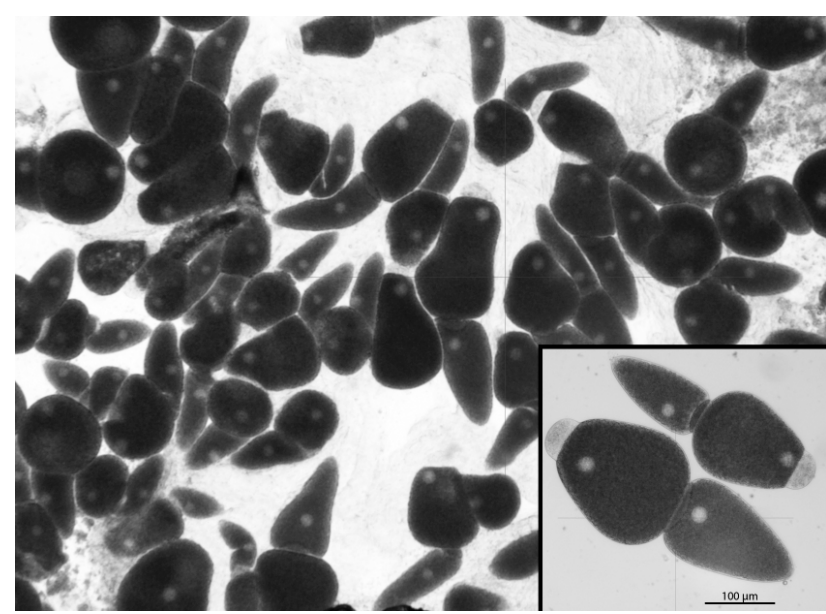

Fig. 1. Gregarina barbarara found in the gut of Harmonia axyridis. In the lower right corner, four magnified mature trophozoites in syzigium.

Nematodes were found in 5 specimens. Infestation was strongly sex-biased, as the parasites were present only in male ladybirds. Nematodes were found in $0.4 \%$, with a median number of 10 individuals per host $(90 \%$ confidence interval: $3-14$ ), and a variance/mean ratio of 10.58 . All the nematodes belonged to the genus Parasitylenchus Wachek, 1955 (Fig. 2).

\section{DISCUSSION}

The population of ladybirds studied was strongly female biased. This strongly skewed sex ratio might be related to the occurrence of male-killing bacteria, like Wolbachia spp. (Hurst et al., 1999b), Rickettsia spp. (Werren et al., 1994) and Spiroplasma spp. (Hurst et al., 1999a), however, their prevalence in the population studied was low (Dudek et al., 2017).

Although the gregarine G. barbarara was found only in $1.5 \%$ of the $H$. axyridis sampled, this finding is the first solid evidence of a gregarine infecting $H$. axyridis (Roy et al., 2011). The three-fold higher prevalence and infestation intensity in males than females are hard to explain. The low prevalence of gregarines and a scarcity of previous data on the infestation of the multicoloured Asian ladybird (only Kuznetsov, 1997, which mentions that $H$. axyridis is infected by Gregarina in the Far East of Russia) may indicate a recent adaptation of these pathogens to this non native species or fluctuations in the prevalence level. Further studies are needed to explain this phenomenon.

The nematodes were identified as Parasitylenchus sp. Members of this genus are already known as parasites of $H$. axyridis in several European countries (Harding et al., 2011; Poinar \& Steenberg, 2012; Haelewaters et al., 2017). The recorded proportion of infected ladybirds was low $(0.4 \%)$. However, as only digestive tracts and not body cavities were examined, the actual nematode prevalence was certainly higher.

During this study, no infection by the Laboulbeniales fungi was recorded. This is surprising because studies on some American and European populations show a high prevalence of $H$. virescens in $H$. axyridis (Garcés

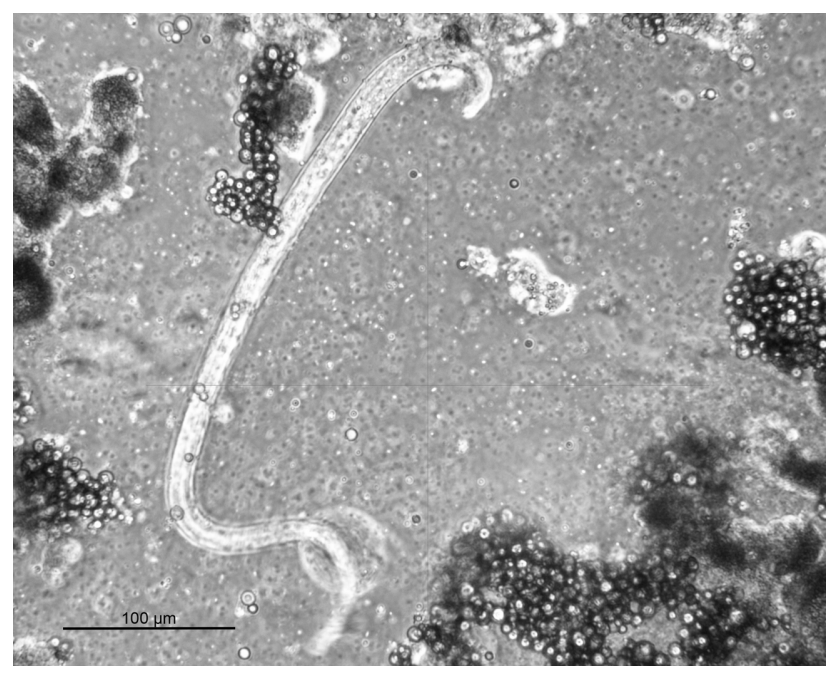

Fig. 2. Parasitylenchus sp. nematode found in the gut of the ladybird Harmonia axyridis.

\& Williams, 2004; Nalepa \& Weir, 2007; Ceryngier \& Twardowska, 2013; Haelewaters et al., 2017), and this prevalence tends to be highest in winter [55-60\% (Garcés \& Williams, 2004) and 62\% (Nalepa \& Weir, 2007)].

Neither parasitic nor phoretic mites were recorded on the individuals of $H$. axyridis examined, so it can be concluded that the mites do not use, or rarely use this ladybird species as a host or a means of transport. Lack of reports of observations of phoretic mites on $H$. axyridis in the literature indicates that this coccinellid is avoided of them, like majority of the other species of ladybirds.

ACKNOWLEDGEMENTS. This work was supported by the National Science Centre, Poland (scholarship ETIUDA 2016/20/T/ NZ8/00134) and by Poznań University of Life Sciences (a grant for young scientists, no. 507.511.5). We thank the editor and two reviewers for many valuable comments, which improved the manuscript.

\section{REFERENCES}

Bollatti F. \& Ceballos A. 2014: Effect of gregarines (Apicomplexa: Sporozoa) on survival and weight loss of Victorwithius similis (Arachnida: Pseudoscorpiones). - J. Invertebr. Pathol. 117: $13-18$.

Carroll S.P., Loye J.E., Dingle H., Mathieson M., Famula T.R. \& ZALUCKI M.P. 2005: And the beak shall inherit - evolution in response to invasion. - Ecol. Lett. 8: 944-951.

Ceryngier P. \& Hodek I. 1996: Enemies of Coccinellidae. In Hodek I. \& Honek A. (eds): Ecology of Coccinellidae. Springer, Dordrecht, pp. 319-350.

Ceryngier P. \& Twardowska K. 2013: Harmonia axyridis (Coleoptera: Coccinellidae) as a host of the parasitic fungus Hesperomyces virescens (Ascomycota: Laboulbeniales, Laboulbeniaceae): A case report and short review. - Eur. J. Entomol. 110: $549-557$.

Ceryngier P., Roy H.E \& Poland R.L. 2012: Natural enemies of ladybird beetles. Ecology and behaviour of the ladybird beetles (Coccinellidae). In Hodek I., van Emden H.F. \& Honek A. (eds): Ecology and Behaviour of the Ladybird Beetles (Coccinellidae). Blackwell, Chichester, pp. 375-443.

Clopton R., Lee J. \& Leedale G. 2002: Phylum Apicomplexa Levine, 1970: Order Eugregarinorida Léger, 1900. In Lee J.J., 
Leedale G., Patterson D. \& Bradbury P.C. (eds): Illustrated Guide to the Protozoa. Society of Protozoologists, Lawrence, KS, pp. 205-288.

Colautti R.I., Ricciardi A., Grigorovich I.A. \& Macisaac H.J. 2004: Is invasion success explained by the enemy release hypothesis? - Ecol. Lett. 7: 721-733.

Cottrell T.E. \& Shapiro-Ilan D.I. 2003: Susceptibility of a native and an exotic lady beetle (Coleoptera: Coccinellidae) to Beauveria bassiana. - J. Invertebr. Pathol. 84: 137-144.

Dudek K., Dudek M. \& TRYjanowski P. 2015: Wind turbines as overwintering sites attractive to an invasive lady beetle, Harmonia axyridis Pallas (Coleoptera: Coccinellidae). - Coleopt. Bull. 69: 665-669.

Dudek K., Humińska K., Wojciechowicz J. \& Tryjanowski P. 2017: Metagenomic survey of bacteria associated with the invasive ladybird Harmonia axyridis (Coleoptera: Coccinellidae). — Eur. J. Entomol. 114: 312-316.

El-Hariri G. 1966: Records of nematode parasites of Adalia bipunctata (L.) (Col. Coccinellidae). — Entomol. Mon. Mag. 101: 132.

Garcés S. \& Williams R. 2004: First record of Hesperomyces virescens Thaxter (Laboulbeniales: Ascomycetes) on Harmonia axyridis (Pallas) (Coleoptera: Coccinellidae). - J. Kans. Entomol. Soc. 77: 156-158.

Geus A. 1969: Sporentierchen, Sporozoa. Die Gregarida der landund süszwasserbewohnenden Arthropoden Mitteleuropas. In Dahl F., Dahl M. \& Peus F. (eds): Die Tierwelt Deutschlands und der angrenzenden Meeresteile nach ihren Merkmalen und nach ihrer Lebensweise. Vol. 57. VEB Gustav Fisher, Jena, 608 pp.

Ginsberg H.S., Lebrun R.A., Heyer K. \& Zhioua E. 2002: Potential nontarget effects of Metarhizium anisopliae (Deuteromycetes) used for biological control of ticks (Acari: Ixodidae). - Environ. Entomol. 31: 1191-1196.

Gudowska A., Drobniak S.M., Schramm B.W., Labecka A.M., Kozlowski J. \& Bauchinger U. 2015: Hold your breath beetle - Mites! - Evolution 70: 249-255.

GwiazDowicz D. 2000: Mites (Acari, Gamasida) associated with insects in the Białowieża National Park. — Acta Parasitol. 45: $43-47$.

Haelewaters D., Comont R.F., Zhao S.Y. \& Pfister D.H. 2014: Hesperomyces virescens (Fungi, Ascomycota, Laboulbeniales) attacking Harmonia axyridis (Coleoptera, Coccinellidae) in its native range. - Chin. Sci. Bull. 59: 528-532.

Haelewaters D., Zhao S.Y., Clusella-Trullas S., Cottrell T.E., Kesel A., Fiedler L., Herz A., Hesketh H., Hui C., Kleespies R.G. ET AL. 2017: Parasites of Harmonia axyridis: current research and perspectives. - BioControl 62: 355-371.

Harding S., Poinar Jr G.O., Dimitrova D.V. \& Steenberg T. 2011: Parasitylenchus sp. (Tylenchomorpha: Allantonematidae) parasitizing field populations of Harmonia axyridis (Coleoptera: Coccinellidae). — Eur. J. Entomol. 108: 487-488.

Heger T. \& JeschKe J.M. 2014: The enemy release hypothesis as a hierarchy of hypotheses. - Oikos 123: 741-750.

Hurst G.D., Majerus M.E. \& Fain A. 1997: Coccinellidae (Coleoptera) as vectors of mites. - Eur. J. Entomol. 94: 317-319.

Hurst G.D., Schulenburg J., Majerus T., Bertrand D., Zakharov I., Baungaard J., Völkl W., Stouthamer R. \& MAJERUS M. 1999a: Invasion of one insect species, Adalia bipunctata, by two different male-killing bacteria. - Insect Mol. Biol. 8: 133-139.

Hurst G.D., Jiggins F.M., von der Schulenburg J.H.G., Bertrand D., West S.A., Goriacheva I.I., ZaKharov I.A., WerRen J.H., Stouthamer R. \& Majerus M.E. 1999b: Male-killing
Wolbachia in two species of insect. - Proc. R. Soc. Lond. (B) Biol. Sci. 266: 735-740.

Inglis G.D., Goettel M.S., Butt T.M. \& Strasser H. 2001: Use of hyphomycetous fungi for managing insect pests. In Butt T.M., Jackson C. \& Magan N. (eds): Fungi as Biocontrol Agents: Progress, Problems and Potential. CAB International, Wallingford, pp. 23-69.

Keane R.M. \& Crawley M.J. 2002: Exotic plant invasions and the enemy release hypothesis. - Trends Ecol. Evol. 17: 164170 .

Kuznetsov V. 1997: Lady Beetles of the Russian Far East. Center for Systematic Entomology, Gainesville, FL, 248 pp.

Lemire S., Coderre D., Vincent C. \& Belair G. 1996: Lethal and sublethal effects of the entomogenous nematode, Steinernema carpocapsae, on the coccinellid Harmonia axyridis. - Nematropica 26: 284-285.

LIPA J.J. 1967: Studies on gregarines (Gregarinomorpha) of arthropods in Poland. - Acta Protozool. 5: 97-223.

Logan J.D., JANOVy J. \& Bunker B.E. 2012: The life cycle and fitness domain of gregarine (Apicomplexa) parasites. - Ecol. Modell. 233: 31-40.

Lopes R.B. \& Alves S.B. 2005: Effect of Gregarina sp. parasitism on the susceptibility of Blattella germanica to some control agents. - J. Invertebr. Pathol. 88: 261-264.

Mitchell C.E. \& Power A.G. 2003: Release of invasive plants from fungal and viral pathogens. - Nature 421: 625-627.

Nalepa C.A. \& WeIR A. 2007: Infection of Harmonia axyridis (Coleoptera: Coccinellidae) by Hesperomyces virescens (Ascomycetes: Laboulbeniales): role of mating status and aggregation behavior. - J. Invertebr. Pathol. 94: 196-203.

NGUYen K. 2010: Insect Nematodes. URL: http://entnemdept. ifas.ufl.edu/nguyen/insectnema/insect-nematodes.html (last accessed 12 Apr. 2010).

NIKIFOROV G. 1970: The characteristics of a massive outbreak of the Siberian Lasiocampid. - Zash. Rast. 15: 38-39.

Pell J. \& Vandenberg J.V. 2002: Interactions among the aphid Diuraphis noxia, the entomopathogenic fungus Paecilomyces fumosoroseus and the coccinellid Hippodamia convergens. Biocontr. Sci. Technol. 12: 217-224.

Pell J.K., Eilenberg J., HajeK A.E. \& Steinkraus D.C. 2001: Biology, ecology and pest management potential of Entomophthorales. In Butt T.M., Jackson C. \& Magan N. (eds): Fungi as Biocontrol Agents: Progress, Problems and Potential. CAB International, Wallingford, pp. 71-154.

Pingel R.L. \& Lewis L.C. 1996: The fungus Beauveria bassiana (Balsamo) Vuillemin in a corn ecosystem: Its effect on the insect predator Coleomegilla maculata De Geer. - Biol. Contr. 6: $137-141$.

PoINAR G. \& PoINAR R. 1998: Parasites and pathogens of mites. - Annu. Rev. Entomol. 43: 449-469.

Poinar G.O. \& SteEnBerg T. 2012: Parasitylenchus bifurcatus n. sp. (Tylenchida: Allantonematidae) parasitizing Harmonia axyridis (Coleoptera: Coccinellidae). - Parasit. Vectors 5: $218,8 \mathrm{pp}$.

RhamHalinghan M. 1987a: Host-parasite relationship in Coccinella septempunctata L. (Coleoptera, Coccinellidae) and Coccinellimermis Rubtzov (Nematoda, Mermithidae). $-J$. Adv. Zool. 8: 94-99.

RhamHalinghan M. 1987b: Pathophysiological effects on the ovaries in Coccinellimermis Rubtzov (Nematoda: Mermithidae) infected Coccinella septempunctata L. (Coleoptera: Coccinellidae): A preliminary report. — Proc. Ind. Natn. Sci. Acad. 1: $31-34$. 
Roy H.E. \& PeLl J.K. 2000: Interactions between entomopathogenic fungi and other natural enemies: implications for biological control. - Biocontr. Sci. Technol. 10: 737-752.

Roy H.E., Brown P.M., Rothery P., Ware R.L. \& Majerus M.E. 2008: Interactions between the fungal pathogen Beauveria bassiana and three species of coccinellid: Harmonia axyridis, Coccinella septempunctata and Adalia bipunctata. - BioControl 53: 265-276.

Roy H.E., Rhule E., Harding S., Handley L.J.L., Poland R.L., Riddick E.W. \& STEENBerg T. 2011: Living with the enemy: parasites and pathogens of the ladybird Harmonia axyridis. BioControl 56: 663-679.

Rózsa L., Reiczigel J. \& Majoros G. 2000: Quantifying parasites in samples of hosts. - J. Parasitol. 86: 228-232.

Tarasco E., De Bievre C., Papierok B., Poliseno M., Triggiani O. \& De Bievre C. 1997: Occurrence of entomopathogenic fungi in soils in Southern Italy. - Entomologica 31: 157-166.

Todorova S., Côté J.C. \& Coderre D. 1996: Evaluation of the effects of two Beauveria bassiana (Balsamo) Vuillemin strains on the development of Coleomegilla maculata lengi Timberlake (Col., Coccinellidae). — J. Appl. Entomol. 120: 159-163.
Torchin M., LAfFerTy K. \& Kuris A. 2002: Parasites and marine invasions. - Parasitology 124: 137-151.

Torchin M.E., Lafferty K.D., Dobson A.P., McKenzie V.J. \& KURIS A.M. 2003: Introduced species and their missing parasites. - Nature 421: 628-630.

Vilcinskas A., MukherJee K. \& Vogel H. 2013: Expansion of the antimicrobial peptide repertoire in the invasive ladybird Harmonia axyridis. — Proc. R. Soc. (B) 280: 20122113, 9 pp.

VoronTsov A. 1995: Forest Entomology Manual for Universities. 5th ed. Ecologia, Moscow, $352 \mathrm{pp}$.

Ware R., Michie L.J., Otani T., Rhule E. \& Hall R. 2010: Adaptation of native parasitoids to a novel host: the invasive coccinellid Harmonia axyridis. - IOBC/WPRS Bull. 58: 175-182.

Werren J.H., Hurst G., Zhang W., Breeuwer J., Stouthamer R. \& MAJERUs M. 1994: Rickettsial relative associated with male killing in the ladybird beetle (Adalia bipunctata). - J. Bacteriol. 176: 388-394.

Received March 31, 2017; revised and accepted July 13, 2017 Published online July 26, 2017 